\title{
Age of Differentiation Determines Rat Retinal Germinal Cell Phenotype: Induction of Differentiation by Dissociation
}

\author{
T. A. Reh and I. J. Kljavin \\ Neuroscience Research Group, Department of Medical Physiology, Lion's Sight Center, Faculty of Medicine, University of \\ Calgary, Calgary, Alberta T2N 1N4, Canada
}

\begin{abstract}
We are interested in the mechanisms that control cell phenotype during the development of the CNS. Since different neuronal types arise at different times during neurogenesis in the retina, we predicted that the factors that determine cell type must be developmentally regulated as well. To test this hypothesis, we induced retinal germinal cells to differentiate at different ages by dissociating the retina into single cells and culturing them on a variety of substrates. Prior to dissociation, the S-phase germinal cells were labeled with 3H-thymidine so that their fate could be specifically followed. We found that our culture conditions promoted the differentiation of the majority of the germinal cells and that these cells differentiated into different neuronal types depending on the age of the animal from which the retina had been taken; embryonic day 14 germinal cells differentiated primarily into ganglion cells, and never produced rods, while germinal cells from postnatal day 1 retina differentiated into rods, but not ganglion cells. These results are consistent with the hypothesis that temporally regulated factors determine cell phenotype during the development of the retina.
\end{abstract}

The retina, like most areas of the CNS, is derived from a precursor cell population known as the germinal neuroepithelium. It has been well established that these cells give rise to the various types of neurons and glia within the CNS; however, there is little known about the mechanisms that are responsible for controlling the diversity of the progeny of these multipotent precursor cells.

One property of the germinal cells which appears to be characteristic of most areas of the CNS is that the various types of neurons and glia that comprise a particular region are generated during development in a regular sequence (see Jacobson, 1978, for a review). In the cerebral cortex, for example, the cells of each cortical lamina are "born" in a roughly inside-out fashion, while in the vertebrate retina, ganglion cells, horizontal cells, and cones are the first cells to become postmitotic, with amacrine cells, rods, bipolar cells, and Müller glia born later (frog: Hollyfield, 1968; chick: Kahn, 1974; mouse: Sidman, 1961; Blanks and Bok, 1977; Hinds and Hinds, 1978, 1979; Carter-

\footnotetext{
Received Mar. 21, 1989; revised May 30, 1989; accepted May 31, 1989

We gratefully acknowledge the excellent technical assistance of A. Ertimaier and also thank Dr. D. Bowling for critical comments on the manuscript. T.A.R. is a Sloan Foundation Fellow and a Scholar of the Alberta Heritage Foundation for Medical Research. This work was supported by a grant from the Medical Research Council of Canada.

Correspondence should be addressed to Dr. T. A. Reh, Department of Biological Structure, University of Washington SM-20, Seattle, WA 98195.

Copyright (C) 1989 Society for Neuroscience $0270-6474 / 89 / 124179-11 \$ 02.00 / 0^{\circ}$
}

Dawson and LaVail, 1979; Young, 1985; cat: Rappaport and Stone, 1983; Zimmerman et al., 1988; monkey: Rappaport et al., 1988; rat: Bok, 1968; Turner and Cepko, 1987; M. LaVail, unpublished observations). Is this regular and well-conserved sequence of birthdates essential for the appropriate determination of cell phenotype during development? In this study we have asked whether the time at which a cell becomes postmitotic determines the type of neuron it ultimately becomes, by prematurely inducing the differentiation of retinal germinal neuroepithelial cells at 2 different times during neurogenesis and determining the resultant phenotypes of the differentiated neurons arising from these cells.

\section{Materials and Methods}

Sprague-Dawley or Long-Evans rats were used in these experiments. Pregnancies were timed from the sperm-positive date and were either 21 or $22 \mathrm{~d}$ in duration. The day of birth was designated as PO. We used retinas from animals of 3 ages in this study: embryonic day 14 (E14) and postnatal days 1 and 3 (P1 and P3). For the embryonic animals, the pregnant females were killed with ether, and the fetuses were removed. Postnatal animals were also killed with ether. In all cases the retinas were dissected from the surrounding ocular tissues and incubated sequentially in a solution of EDTA (1 mM in basal salt solution) and trypsin $(0.25 \%)$ to dissociate the cells. We found that the optimum times of incubation in the dissociation solutions varied with developmental age; at E14 we used incubation times of 5 min for each solution, while the times were extended to $20 \mathrm{~min}$ in each solution for the P1 and P3 animals. After this treatment, the trypsin was inactivated with fetal bovine serum (FBS), and the retinas were dissociated into a single-cell suspension by gentle trituration. The cells were then plated in 24 well tissue culture plates on glass coverslips that had been previously treated with one of the following substrates: (1) rat tail collagen (Coliaborative Research, Bedford, MA) air-dried, $1 \mathrm{mg} / \mathrm{ml}$; (2) poly-L-lysine (Sigma, St. Louis, MO) $10 \mu \mathrm{g} / \mathrm{ml}$; (3) EHS-sarcoma basement membrane (Matrigel, Collaborative Research, or as a gift from Dr. H. Kleinman). The culture media was DMEM (GIBCO) supplemented with $10 \%$ FBS and antibiotics. In some experiments, the $S$-phase germinal cells were laheled by incubating the retinas in media with ${ }^{3} \mathrm{H}$-thymidine $(1 \mu \mathrm{Ci} / \mathrm{ml}$ of a 6.7 $\mathrm{Ci} / \mathrm{mmol}$ solution, New England Nuclear) for 6 (E14) or 12 (P1) hr prior to dissociation. The retinas were then rinsed 3 times in nonradioactive thymidine $\left(10^{-7} \mathrm{M}\right)$ containing media and then dissociated as described above. These cells were then allowed to grow in vitro for 2-6 d to determine the types of neurons into which the germinal cells would differentiate.

After periods of 2-6 d in culture, retinal cells from either postnatal ages or E14 were fixed in $2 \%$ paraformaldehyde for $20 \mathrm{~min}$, rinsed with PBS, and incubated in one of several antibodies to determine the types of neurons in the cultures. Retinal ganglion cells were identified by using thy-1.1 (OX7 clone, Cedarlane Labs, Ontario, Canada), neurofilament (Boerhringer-Mannheim, FRG; $160 \mathrm{kDa}$ subunit), or B-50/GAP-43 antisera (raised in rabbit and generously supplied by Dr. H. Zwiers; Zwiers et al., 1987; Benowitz et al., 1988). Immunohistochemical staining and in situ hybridizations on developing rat retinal sections indicate that B-50/GAP-43 is expressed primarily in retinal ganglion cells $(T$. A. Reh, W. Tetzlaff, H. Zwiers, and A. Ertlmaier, unpublished obser- 


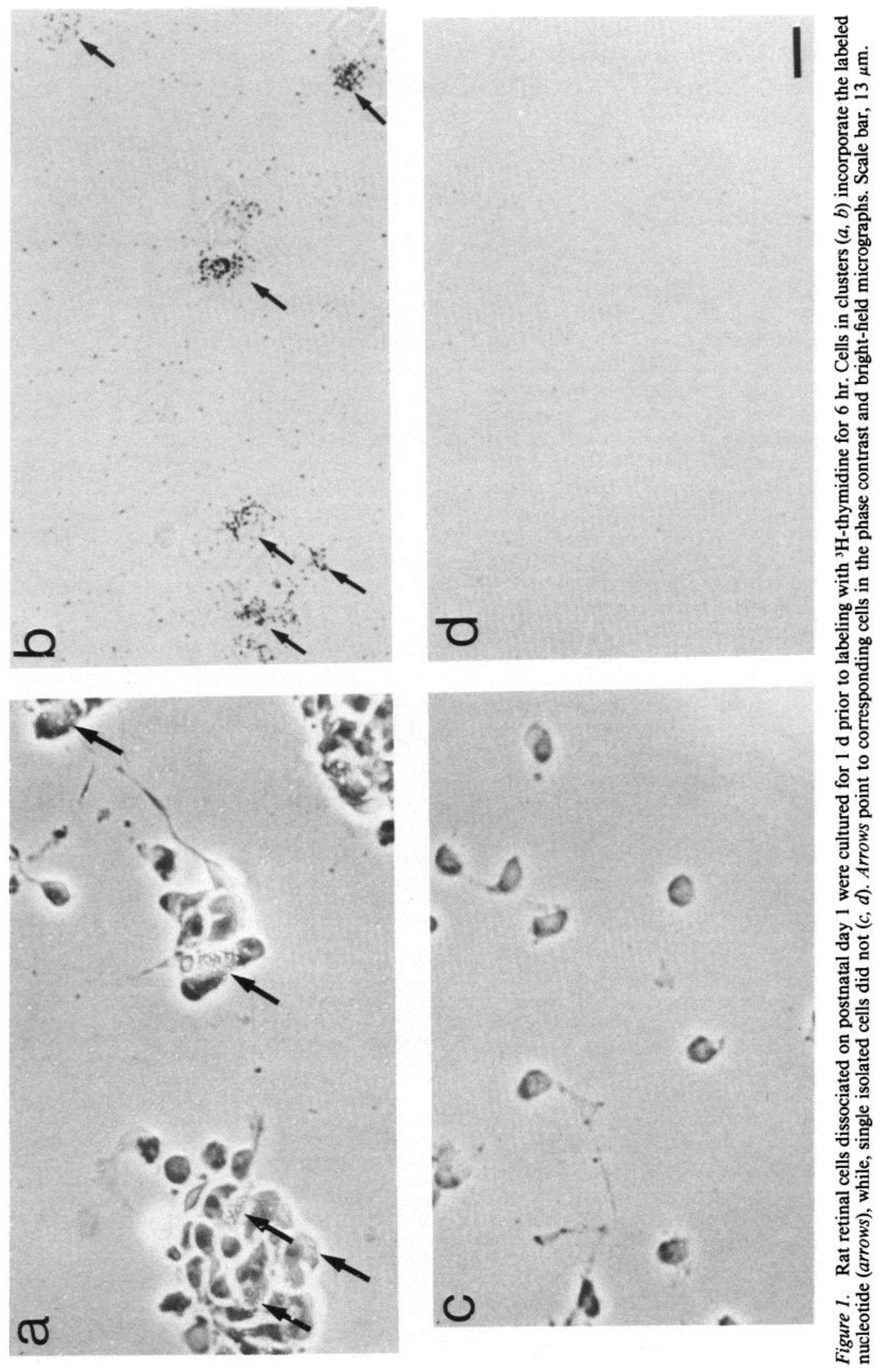


A

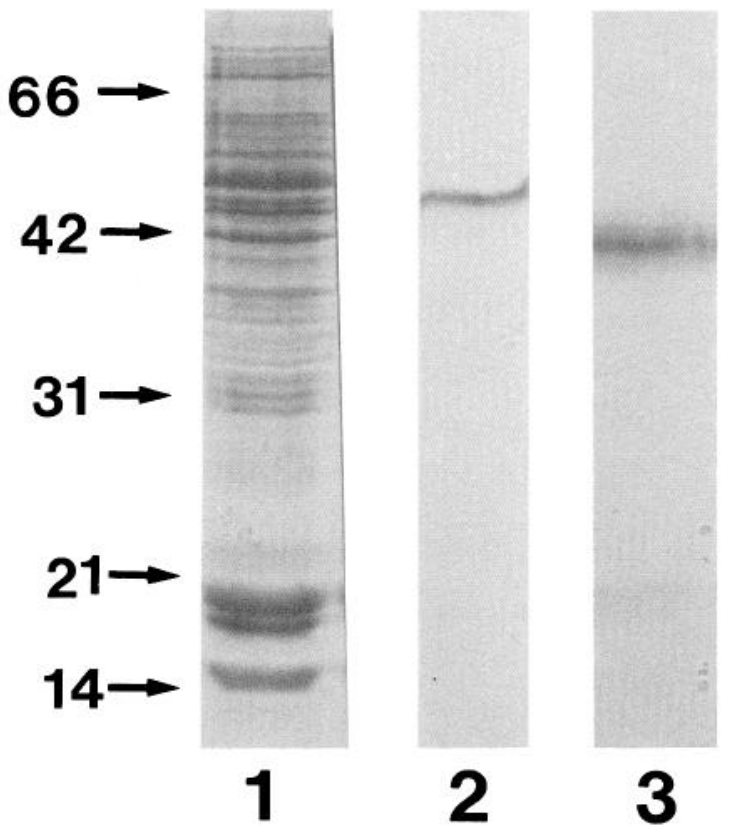

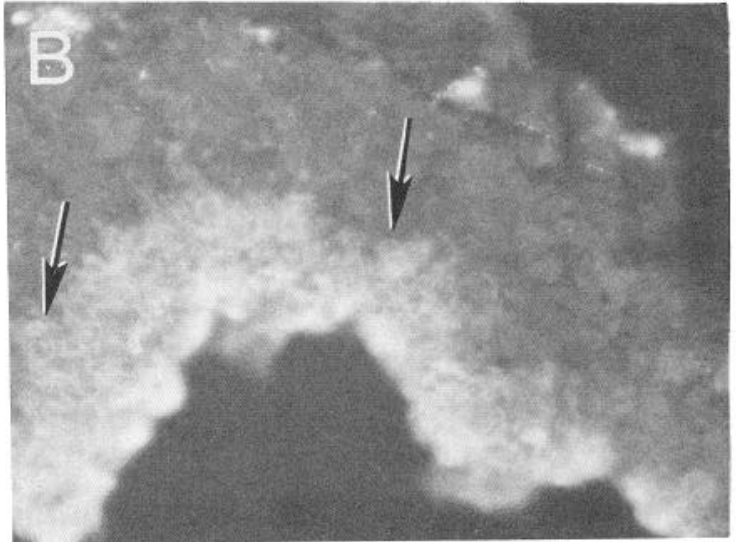

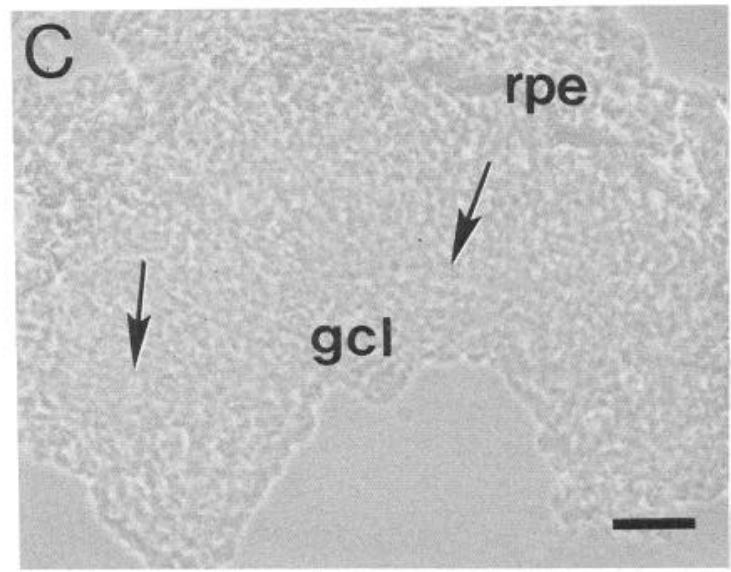

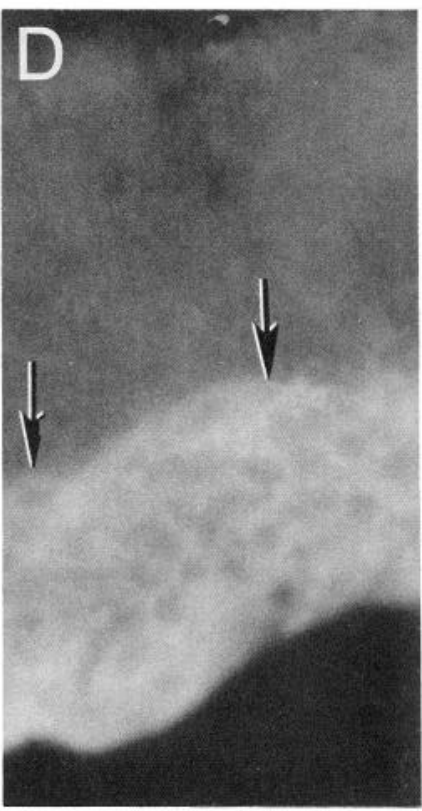
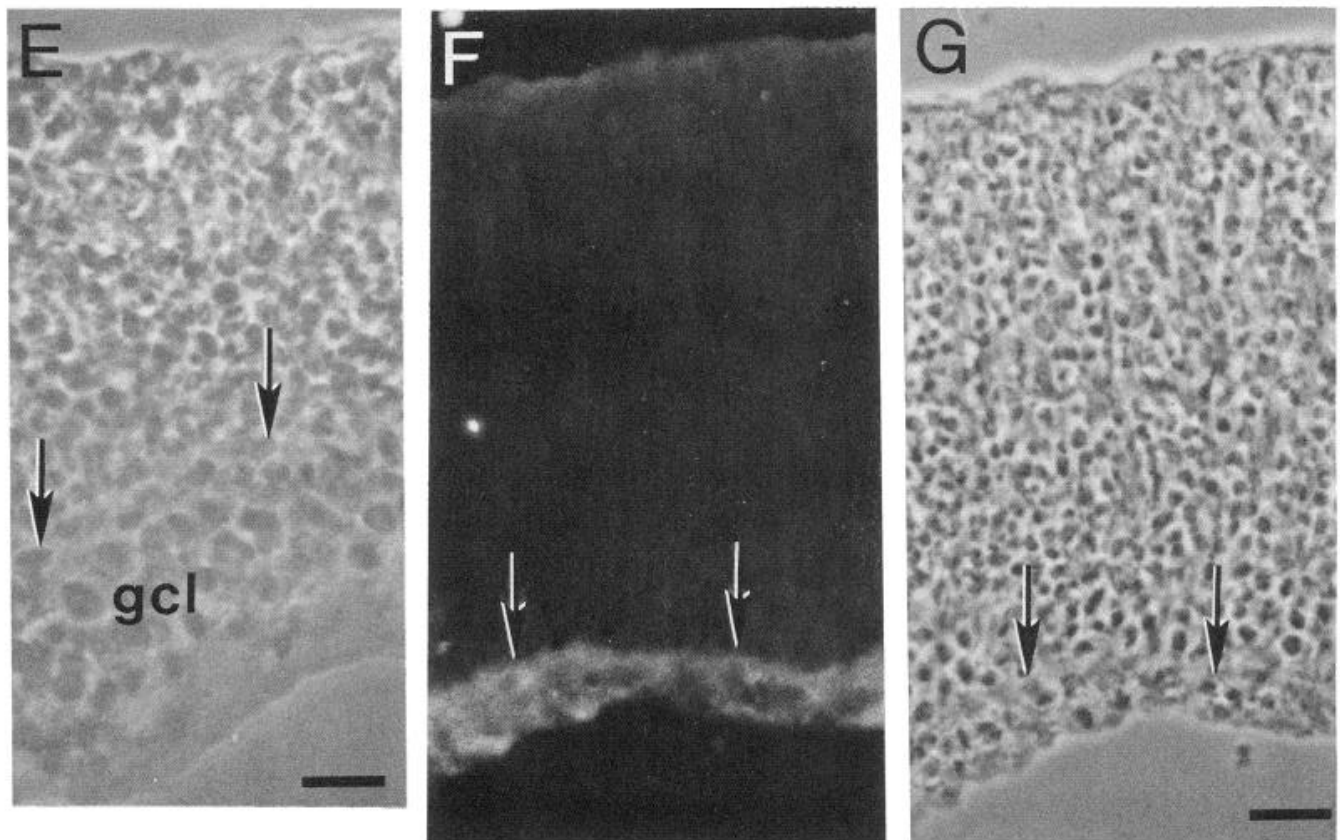

Figure 2. B-50/GAP-43 immunoreactivity is expressed in retinal ganglion cells early in their development. $A$, Immunoblot of retinal protein from a day 6 rat (lane 1: imido black stain of total protein) showing a single band (lane 2) with a molecular weight of approximately $45 \mathrm{kDa}$ after incubation with affinity-purified rabbit antiserum to B-50 (GAP-43). Preabsorption of this antiserum with HPLC purified rat brain B-50 eliminates this staining. Lane 3 shows the same sample incubated with the 4D2 opsin ( $38 \mathrm{kDa})$ monoclonal antibody for comparison. B-G, Photomicrographs of rat retinal sections $(6-8 \mu \mathrm{m})$ from embryonic days $15(B, C)$ and $18(D, E)$ and postnatal day 3 rats $(F, G)$ labeled with B-50 (GAP-43) antiserum. Arrows point to the same cells in the phase and fluorescent panels to delimit the border of the retinal ganglion cell layer. Note that the B-50 (GAP43) immunoreactivity is confined to this layer. Scale bars, $15 \mu \mathrm{m}$. 

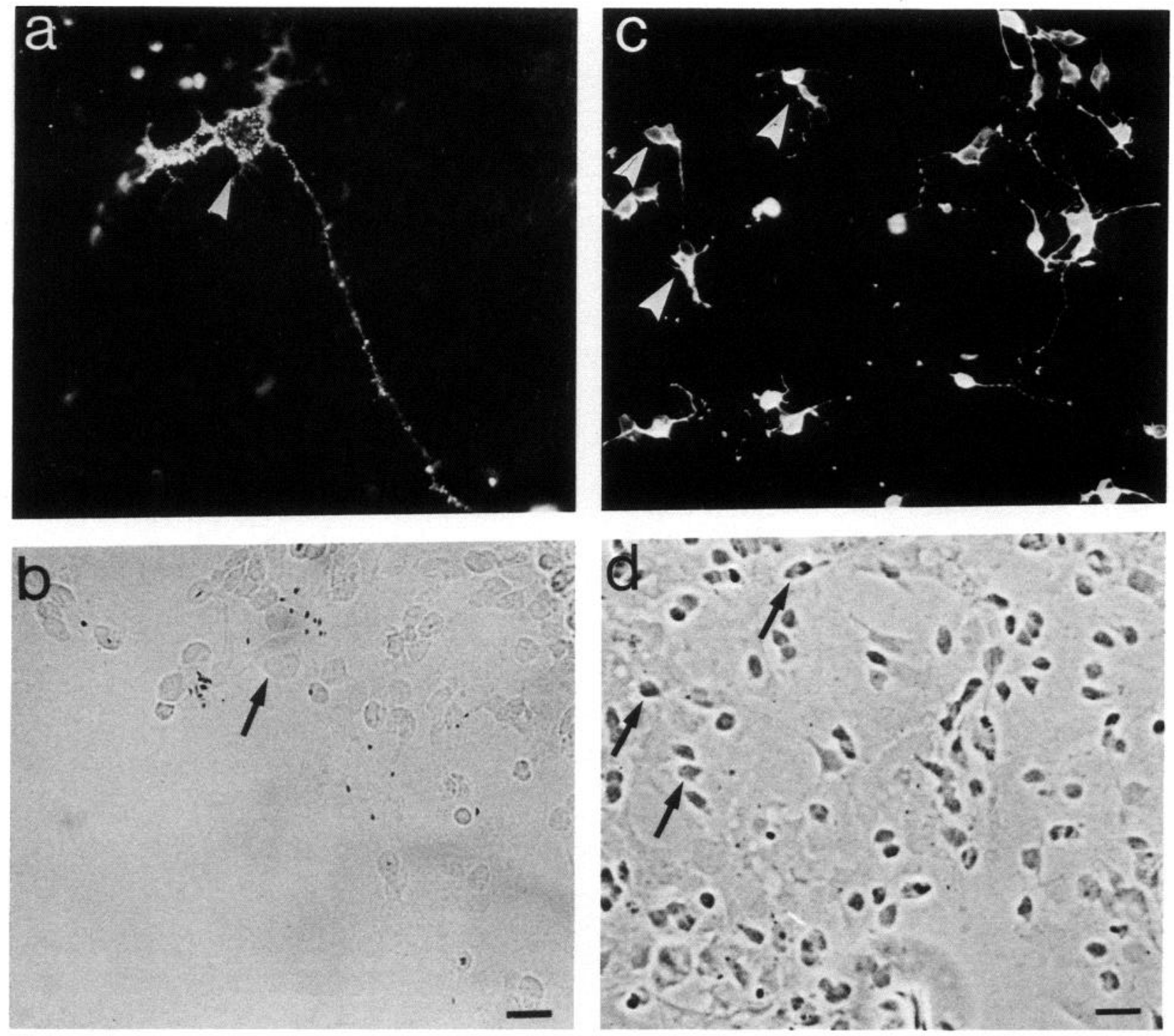

Figure 3. Postnatal day 3 retinal ganglion cells (RGC) and rods after $6 \mathrm{~d}$ in culture. At high density, platings both RGCs (a) and rods $(c)$ extended processes out onto a carpet of glial cells $(b, d)$. In $a$, the RGC is immunofluorescently labeled with thy-1.1, and in $c$, rods are labeled with rho-4D2 directed against rhodopsin, while $b$ and $d$ are the corresponding phase images. Scale bar, $17 \mu \mathrm{m}(a, b)$ and $25 \mu \mathrm{m}(c, d)$.

vations; see Results). Rods were labeled with 1 of 2 monoclonal antibodies generated by Drs. R. Molday and D. Hicks (rho 4D2, C-terminal and rho-2A4, N-terminal). Antibodies were used at approximately 10 $\mu \mathrm{g} / \mathrm{ml}$, followed by biotin-conjugated secondary antibodies (Sigma, St. Louis, MO) and avidin-conjugates to one of several fluorochromes (Molecular Probes, Eugene, OR). Omission of the primary monoclonal antibody or substitution with normal rat serum eliminated the observed immunoreactive labeling of the cells. In the case of the B-50 affinitypurified antiserum, substitution with preimmune serum or preabsorption of the antiserum with HPLC purified rat brain B- 50 eliminated the

\section{Table 1. Percentage of ${ }^{3} \mathrm{H}$-thymidine-labeled cells in $1 \mathrm{~d}$ cultures}

\begin{tabular}{lcc} 
Age & Clusters $(>4$ cells $)$ & Single cells \\
\hline E14 & $28.5 \pm 4.3$ & $1.5 \pm 1.0$ \\
P1 & $7.0 \pm 2.2$ & $0.25 \pm 0.25$
\end{tabular}

Values are means \pm SE: E14, $n=10,422$ cells counted; P1, $n=8,746$ cells counted. Cells were dissociated as described in Materials and Methods and plated on collagen. ${ }^{3} \mathrm{H}$-thymidine was added to the cultures for $6 \mathrm{hr}$ at $1 \mathrm{~d}$ after plating. Cells were fixed and processed for autoradiography. reported immunoreactivity. In those cultures that had been labeled with ${ }^{3} \mathrm{H}$-thymidine, following the antibody staining, the coverslips were glued to glass slides, coated with emulsion (NTB-2, Kodak, Rochester, NY), and allowed to expose for $3 \mathrm{~d}$ before developing by standard methods.

Immunoblotting was carried out on postnatal day 6 rat retinal homogenates (in sample buffer containing $10 \%$ glycerol, $5 \% 2$-mercaptoethanol, $2 \%$ SDS, $0.01 \%$ bromophenol blue, $0.5 \mathrm{~m}$ Tris- $\mathrm{HCl}, \mathrm{pH} 6.8$ ) run on a $12.5 \%$ polyacrylamide gel (Laemmli, 1970). The proteins were transferred to nitrocellulose for $1 \mathrm{hr}$ at $4^{\circ} \mathrm{C}$ in a blotting buffer consisting of $25 \mathrm{~mm}$ Tris, pH 8.3, $192 \mathrm{~mm}$ glycine, and $20 \%$ methanol. The nitrocellulose paper was then blocked in $1 \%$ milk powder and incubated in the primary antibody overnight. To reveal the binding of the primary antibodies, an appropriate secondary antibody, conjugated to alkaline phosphatase was used, followed by reaction with 5-bromo, 4-chloro, 3-indolylphosphate.

\section{Results}

Dissociation induces differentiation

Although it is generally accepted that germinal neuroepithelial mitotic activity is substantially reduced when these cells are dissociated from various areas of the CNS, for the purposes of 

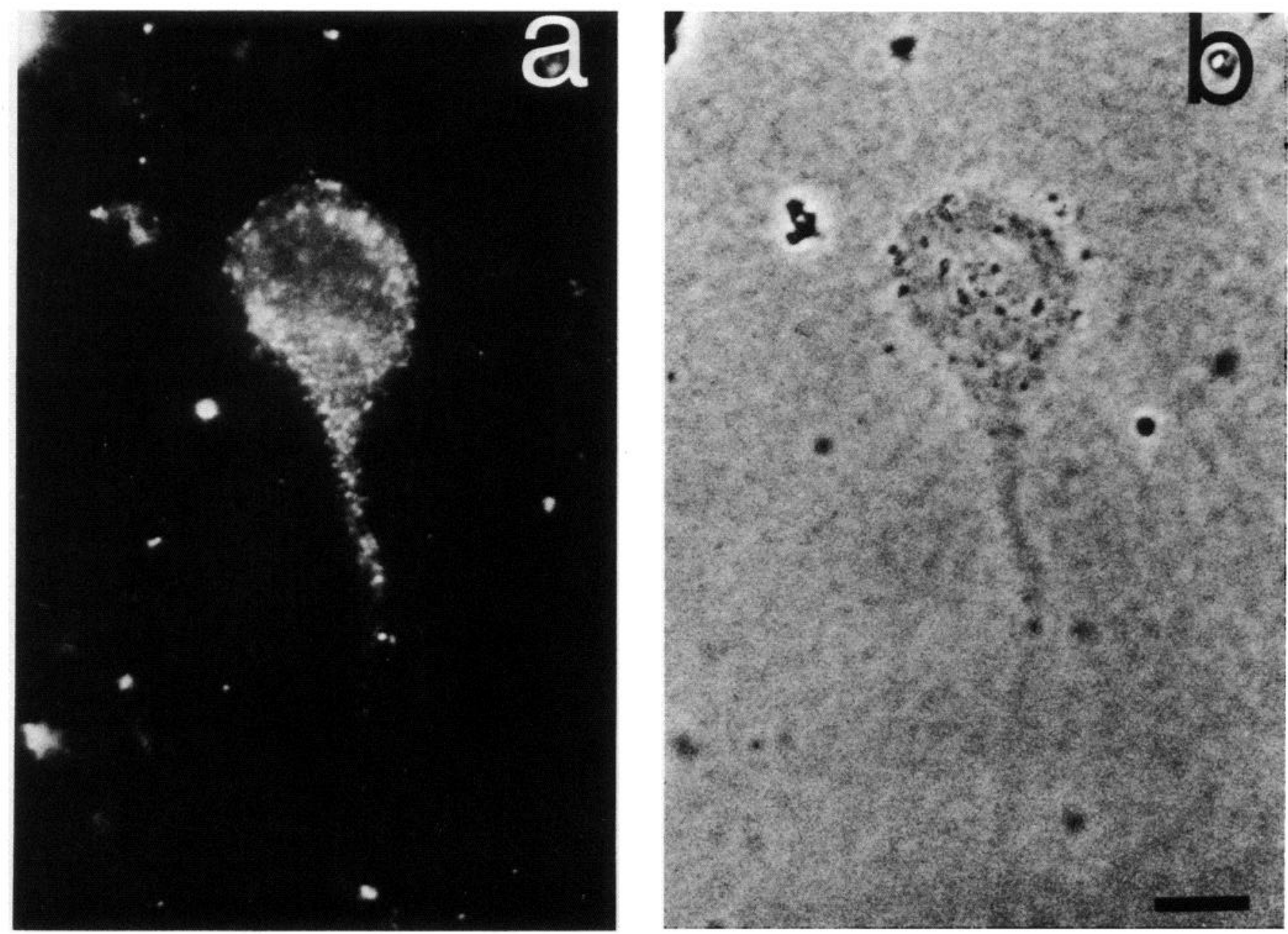

Figure 4. a, Ganglion cell derived from E14 retina and labeled with thy-1.1 antibody after $4 \mathrm{~d}$ in vitro. $b$, Silver grains over the nucleus also demonstrate that this cell had been a mitotically active germinal neuroepithelial cell at the time of dissociation. Scale bar, $6 \mu \mathrm{m}$.

this study, it was important to demonstrate this phenomenon in rat retinal cultures. We did so by preparing dissociated cell cultures from rat retina, at E14 and P1, and plating them on poly-L-lysine substrates. These cultures were then labeled with ${ }^{3} \mathrm{H}$-thymidine after $1 \mathrm{~d}$ in vitro for $6 \mathrm{hr}$. The cells were then fixed and processed for autoradiography. The results are shown in Figure 1 for P1 retina and were similar at E14. When the cells were incompletely dissociated, a substantial number of them found in clusters continued to incorporate the labeled nucleotide (Fig. 1, $a, b$ ); however, when the retinas were completely dissociated into single cells, there was virtually no incorporation of the ${ }^{3} \mathrm{H}$-thymidine (Fig. $1, c, d$ ). Table 1 summarizes the results from the 2 ages we studied; single, isolated cells rarely incorporated the labeled thymidine, whereas clusters containing as few as 4 cells typically contained some labeled ones.

It was also important to establish that the germinal cells were capable of differentiating in culture and that the majority of retinal cells survived the dissociation procedure and the culture conditions through the duration of the experiment. Immediately following the dissociation, we incubated a sample of the cells in a trypan blue solution to assess dye exclusion; we found in most cultures that over $90 \%$ of the dissociated cells were viable by this test. In addition, the majority of the cells that were plated survived in culture for several days. Table 2 shows the cell density in the cultures, as a function of the number of days in vitro, for both E14 and P1 retinal cells. Over the first $6 \mathrm{~d}$ in culture, there is little cell loss at either age and when plated on any of the matrices we tested. After $6 \mathrm{~d}$ in culture, some cell loss occurred; therefore, further analysis of differentiation was confined to those cultures $6 \mathrm{~d}$ or less after dissociation so that the selective loss of neuronal cells would not affect the results.

Table 2. Cell density/day in vitro for E14 and P1 dissociated retinal cells

\begin{tabular}{lll}
$\begin{array}{l}\text { Day in } \\
\text { vitro }\end{array}$ & Density & \\
\cline { 2 - 3 } & E14 & P1 \\
\hline 1 & $33.2 \pm 6.6$ & $36.8 \pm 2.3$ \\
2 & $38.7 \pm 8.2$ & - \\
3 & $35.3 \pm 2.6$ & $28.2 \pm 5.5$ \\
4 & $31.1 \pm 4.6$ & - \\
5 & $32.4 \pm 4.0$ & - \\
6 & $32.3 \pm 2.5$ & $31.75 \pm 4.3$ \\
\hline
\end{tabular}

Cell counts $/ 800 \mu \mathrm{m}^{2} ; 12$ fields were counted at each day after plating; no differences were observed between cell number on the 3 substrates used, so the data were pooled. 

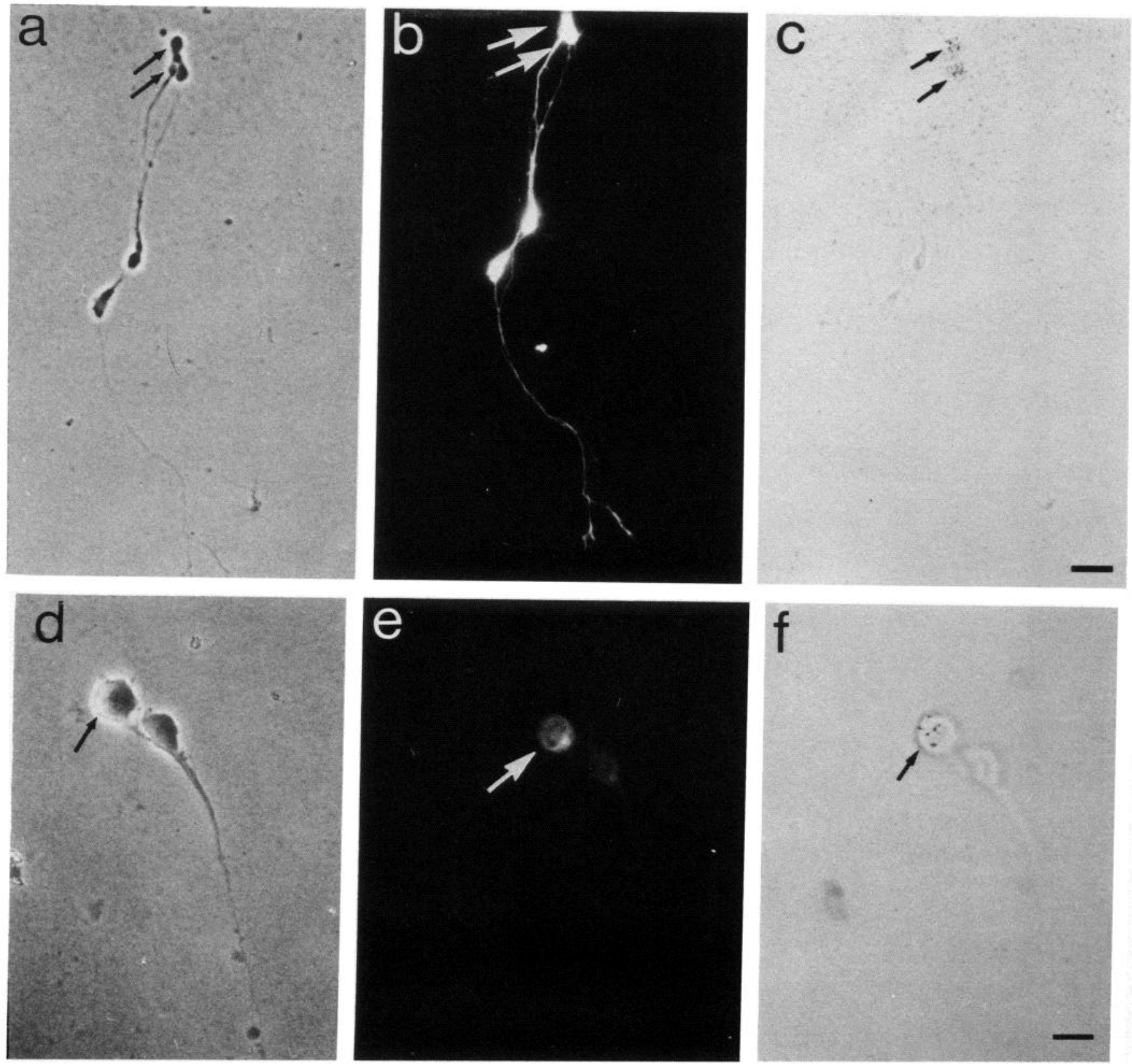

Figure 5. Ganglion cells derived from E14 retina after $4 \mathrm{~d}$ in culture. $a-c$, Corresponding phase, fluorescent, and autoradiographic micrographs of the same field of cells labeled with B-50 antibodies. $d-f$, Corresponding phase, fluorescent, and autoradiographic micrographs of the same 2 cells labeled with a monoclonal antibody to neurofilament. Several of the immunoreactive cells are also labeled with ${ }^{3} \mathrm{H}$-thymidine, as shown by the silver grains over their nuclei (arrows), indicating that they had been in the S phase of the cell cycle within $6 \mathrm{hr}$ of dissociation. Scale bars, $19 \mu \mathrm{m}$ $(a-c), 13 \mu \mathrm{m}(d-f)$.

\section{Immunohistochemical identification of ganglion cells and rods in culture}

Although the monoclonal antibodies used in this study have been thoroughly characterized previously by other investigators, we initially examined their labeling patterns on sections of developing rat retinas, prior to labeling the cultures. We found thy-1.1, opsin, and neurofilament labeling essentially identical to that reported by other studies (Shaw and Weber, 1983; Barnstable and Drager 1984; Hicks and Barnstable, 1987). The thy-1.1 labeling was confined to cells in the ganglion cell layer and their processes at E14, E18, and on postnatal days 1-6. This confirms previous retrograde labeling experiments, where the correspondence between thy-1.1 and the retrogradely transported dye can be as great as 95\% (Barnstable and Drager, 1984; Leifer et al., 1984). The medium molecular-weight subunit of neurofilament (NF160) was also found to label the ganglion cell axons, as well as the cell bodies, although in postnatal animals, some labeling was also found in the outer plexiform layer. This is thought to result from the processes of horizontal cells (Drager, 1983; Shaw and Weber, 1983). The first few opsin-immunoreactive cells are observed at E20 but only occur in substantial numbers in postnatal animals and are always found near the ventricular surface in the developing outer nuclear layer (Hicks 

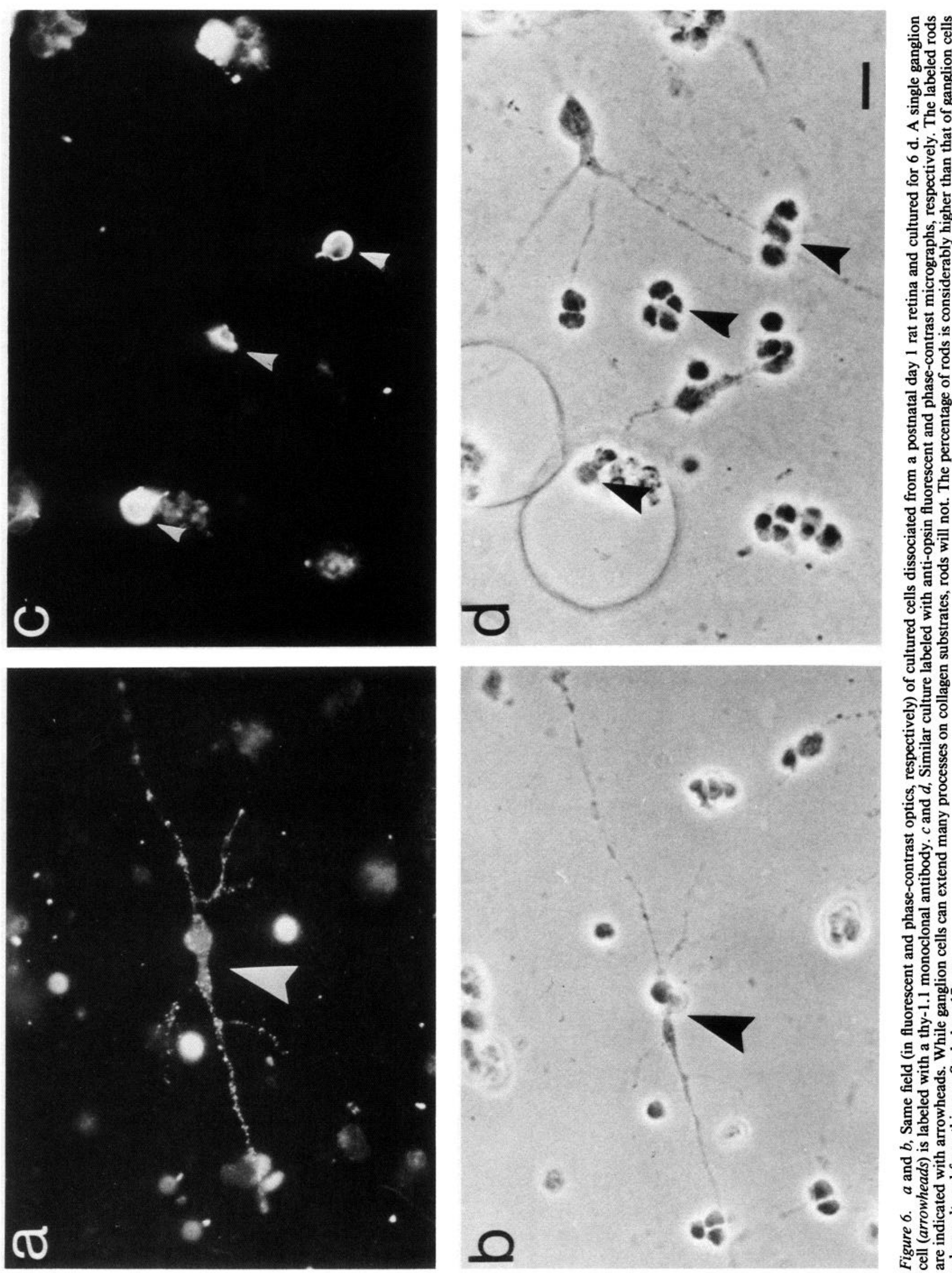

융

즐흥

혀

诺

包的

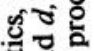

흥즈

의

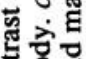

둥명

봉

ส 대

응을

7 등

늘 도

8 해의

两

窟包

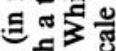

뭉

巴马.

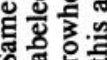

0 .

동호

क 30

\%

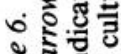

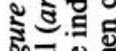

这需 

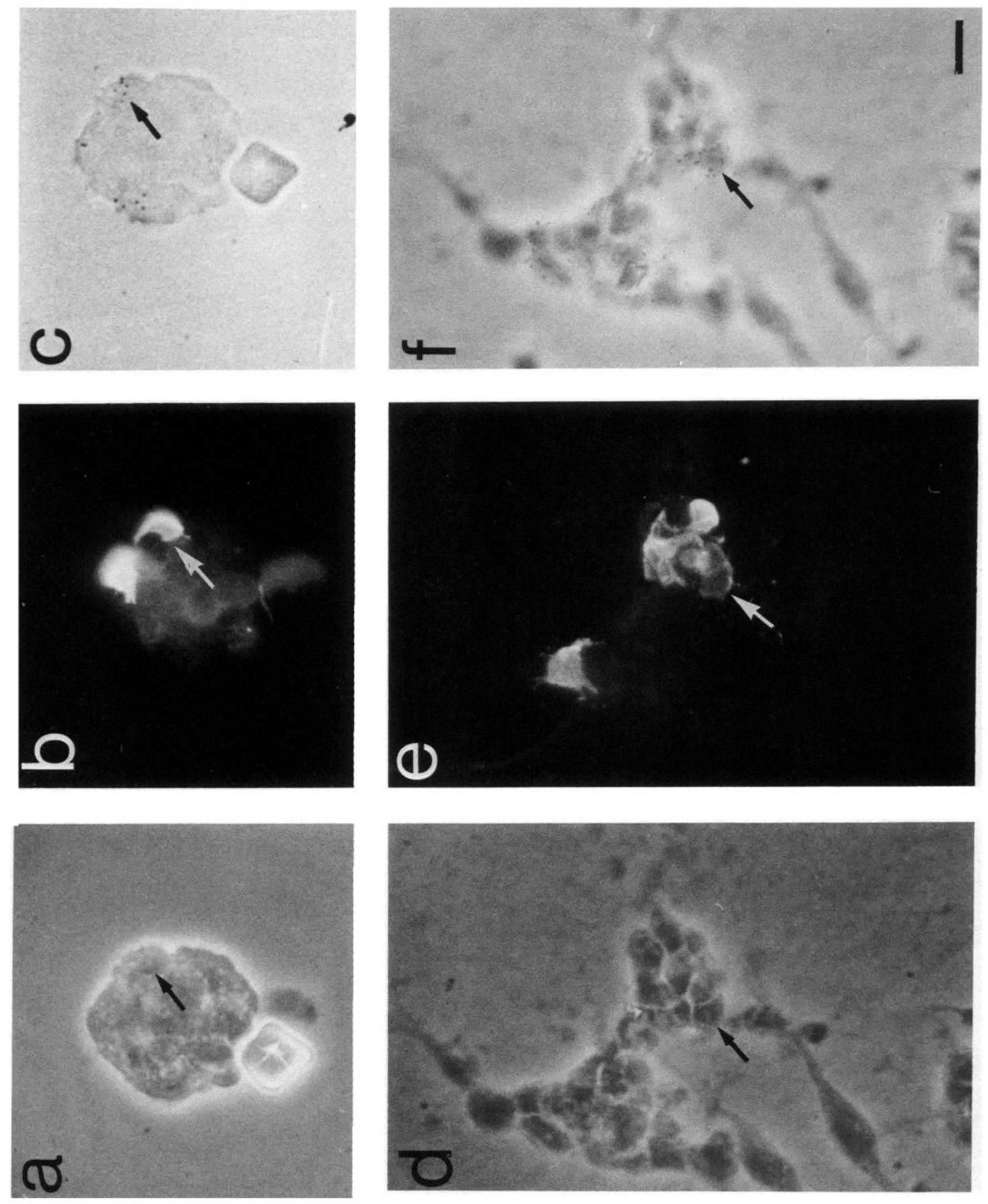

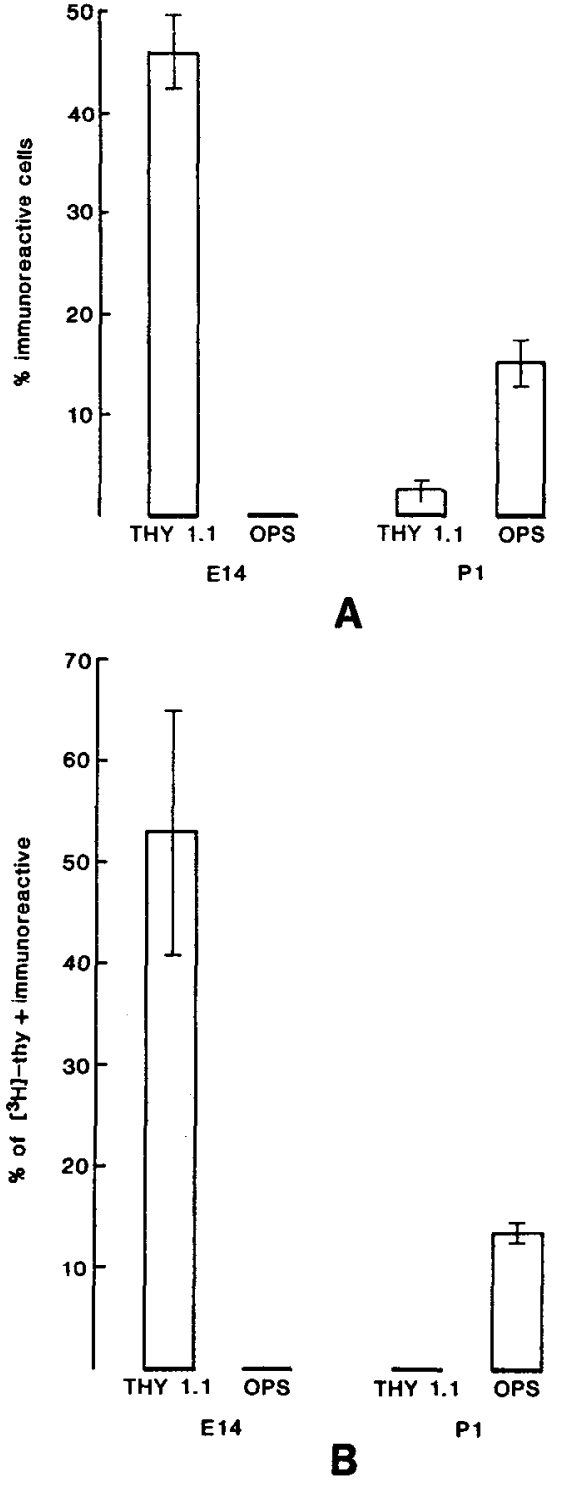

Figure 8. A, Percentages of immunorcactive rods and ganglion cells from dissociated cell cultures of E14 and P1 rat retina. Bars represent means and SE of cell percentages from 2-6 d in vitro from $>6$ total experiments. Six fields from 3 coverslips were counted in each experiment. $B$, Percentages of ${ }^{3} \mathrm{H}$-thymidine-labeled cells that express either thy-1.1 or opsin 2-6 d after dissociation. Bars represent means and SE of the percentage of double-labeled cells from 3 experiments. Six fields from 3 coverslips were counted in each experiment.

and Barnstable, 1987). The localization of B-50/GAP-43 to the ganglion cells layer has not yet been described, although it is perhaps not surprising that this axonally localized molecule (Goslin et al., 1988) should be expressed primarily in the only retinal cells with long axons. Figure 1 demonstrates B-50 immunoreactivity on an immunoblot of a retina from a $6 \mathrm{~d}$ rat pup (lane 2) along with opsin ( $38 \mathrm{kDa})$ immunoreactivity at the same age for comparison (lane 3). Also shown (Fig. $1 b-g$ ) is the location of this antigen within the developing retina at ages E14 (panels $b$ and $c$ ), E18 (panels $d$ and $e$ ), and postnatal day 3 (panels $f$ and $g$ ). In all cases the most intense B-50 immunoreactivity remains confined to the ganglion cells. In situ hybridizations confirm the expression of GAP-43 mRNA only in these cells (Reh et al., unpublished observations).

To determine whether we could reliably identify retinal ganglion cells and rods in our cultures, we plated the cells at a density similar to that used in several previous studies of rat retina (see below), and after a suitable number of days in culture, we fixed the cells and labeled them with the antibodies described above. In the P3 high-density cultures, the aggregates typically spread out over the first week in culture, resulting in the appearance shown in Figure 3. In these cultures, the ncuronal cells sit on top of a carpet of non-neuronal cells, presumably Müller glia and astrocytes (Raju and Bennett, 1986; Wigley and Berry, 1988). As can be seen from the figures, the 2 types of neurons assayed in this study exhibit extensive process extension when growing on the glial cells. Figure $3 a$ shows a typical example of a ganglion cell, labeled with thy-1.1 antibody, in high-density culture, similar to those observed in previous studies (McCaffery et al., 1984; Akagama and Barnstable, 1986; Cohen et al., 1986; Raju and Bennett, 1986; Wigley and Berry, 1988). Both short, tapering dendritic-like processes, as well as a longer, axonal-like process, were present on these cells. These cells survived well under our culture conditions and represented approximately $3 \%$ of the dissociated cells after $6 \mathrm{~d}$ in vitro; this is close to the number of thy-1.1-positive cells we obtained upon acute dissociation at this age $(2.5+0.54 \%)$. Although there have been some reports that ganglion cell survival is dependent on targetderived factors (McCaffery et al., 1984; Raju and Bennett, 1986), others have shown that the intrinsic retinal glia can support ganglion cell survival for up to $18 \mathrm{~d}$ in vitro (Wigley and Berry, 1988), even in ganglion cells obtained from 7-d-old animals.

The other cell type identified in these cultures were rods. These cells, identified by their immunoreactivity to opsin, had only relatively short processes when grown on glial cells, although they may have had anywhere from 1 to 5 of these primary extensions (Fig. 3c). Several previous investigators have described these characteristics of rat rods in culture (Araki et al., 1987; Hicks and Courtois, 1988).

\section{Retinal germinal cells differentiate into different cell types depending on the age of dissociation}

In order to quantify the number of ganglion cells and rods that differentiated at 2 different ages, we needed to culture the cells at low density, approximately $10^{4}$ cells/well in a 24 well plate. In low-density cultures cells remained isolated or in small clusters. Under these conditions, ganglion cells frequently had long processes, while rods extended only very short neurites (less than a cell body in diameter).

Dissociated cultures of E14 retinas contained predominantly one cell type; almost $50 \%$ of the cells from these cultures differentiated into neurons that we could identify as retinal gan-

Figure 7. Rods from a P1 retina, after $6 \mathrm{~d}$ in culture labeled with opsin antibody rho-4D2. $a-c$, Corresponding phase, fluorescent, and autoradiographic micrographs of the samc field; $d-f$. Corresponding phase, fluorescent, and autoradiographic images of another field. Arrows point to those cells that are also labeled with silver grains, indicating they were in the S phase of the cell cycle within $6 \mathrm{hr}$ of dissociation. Scale bar, 12.5 $\mu \mathrm{m}$. 
glion cells on the basis of their positive immunoreactivity to thy-1.1 (Fig. 8A, B-50/GAP-43 (42 + 7\%) and NF160 (53 + 12\%) antibodies (Figs. 4 and 5, respectively). All 3 of these antibodies labeled all the cells in the culture with this simple morphology; a large unipolar cell with a single long axonal-like process extending several hundred microns within a few days of plating. Some of these cells developed additional processes after $3 \mathrm{~d}$ in vitro; however, most retained their unipolar appearance for $6 \mathrm{~d}$ of culturing, regardless of the substrate on which they were plated. Although this simple morphology is not characteristic of ganglion cells dissociated from postnatal retinas, rat retinal ganglion cells do not develop extensive dendritic processes until after birth in vivo (Morrest, 1970), and even after $6 \mathrm{~d}$ in culture, the E14 ganglion cells would not yet have reached this point in their maturation.

In order to determine whether germinal cells were differentiating into ganglion cells following dissociation, in some cultures we prelabeled the germinal neuroepithelial cells for $6 \mathrm{hr}$ with ${ }^{3} \mathrm{H}$-thymidine prior to dissociation. Following extensive washing ( $3 \times$ nonradioactive thymidine-containing media) and dissociation and several days of culture, the coverslips were stained with one of the ganglion cell-specific antibodies mentioned above and processed for autoradiography to identify the percentage of germinal cells that differentiated into ganglion cells in the E14 cultures. We found that over $50 \%$ of the thymidinelabeled germinal cells had differentiated into ganglion cells following dissociation; several examples are shown in Figures 4 and 5 , and the cell counts are summarized in Figure 8 . We also examined the E14 cultures for the presence of rods after 2, 4, and $6 \mathrm{~d}$ in vitro using antibodies to rhodopsin. We never found opsin-positive cells in the E14 cultures at any of these times.

By contrast with the large percentage of ganglion cells in the E14 cultures, this cell type makes up only a small percentage of the cells from P1 retinas (Figs. $6 a, 8 A$ ). While ganglion cells comprise less than $5 \%$ of the neuronal cells, opsin-immunoreactive cells make up approximately $15 \%$ of the $\mathrm{P} 1$ cells (Fig. $6 c$ ). To determine what percentage of germinal cells will give rise to ganglion cells and rods when induced to differentiate in the postnatal retina, we again prelabeled the P1 germinal cells with ${ }^{3} \mathrm{H}$-thymidine for $12 \mathrm{hr}$ prior to dissociation. After several days in culture, followed by immunostaining and processing for autoradiography, as above, the cultures were examined for the presence of double-labeled cells. We found that approximately $10 \%$ of the germinal cells from the P1 retina differentiate into rods when dissociated (Fig. 7); however, we never found a cell that could be identified as a ganglion cell which also had silver grains over the nucleus (Fig. $8 B$ ). Therefore, we conclude that germinal cells induced to differentiate at P1 will differentiate into rods, but not into ganglion cells.

\section{Discussion}

The results of this study can be summarized as follows. Germinal neuroepithelial cells that are induced to differentiate by dissociation produce different neuronal types depending on the age of the animal from which the cells are taken. The types of cells that are thus produced are those that were primarily being generated at the time of the dissociation. Apparently, the germinal cells of the retina "know what time it is." This information could be contributed via mechanisms intrinsic or extrinsic to the germinal cells. Intrinsic mechanisms have been proposed to generate the cellular diversity in such organisms as the nematode, where each cell division occurs in a stereotypic pattern. Although there are some notable exceptions (Sternberg, 1988), the fate of the majority of cells in the nematode are determined autonomously, independent of cell-cell interactions and are likely the result of parceling up intrinsic determinants in a rigid manner (see Sternberg and Horvitz, 1984, for a review). While such autonomous phenotypic specification has been proposed for germinal cells within the mammalian CNS as well (see Herrup and Williams, 1987), recent lineage analysis of retinal germinal cells indicates that no strict, deterministic pattern or arrangement appears to be present in the progeny of these cells (Turner and Cepko, 1987; Wetts and Fraser, 1987; Holt et al., 1988). Any given clone may consist of several different combinations of the various retinal cell types generated after the label is introduced. Therefore, the highly deterministic pattern of division characteristic of lineage-based mechanisms of phenotypic determination do not appear to apply to retinal histogenesis. This conclusion is consistent with a great deal of experimental embryological studies of the developing CNS, in which particular regions of the embryonic nervous system can be induced to change their commitment or regenerate adjacent areas (Detwiler, 1945, 1946; Harrison, 1947; also see Cowan and Finger, 1982, for a review).

Another possibility is that the germinal cells are somehow instructed by their environment to differentiate into particular types of neurons, at a time close to their final mitotic division. This idea was first postulated as a mechanism in retinal neurogenesis by Hinds and Hinds $(1978,1979)$ after a serial section analysis of developing retina. Further evidence for the regulation of neuronal phenotype by the microenvironment of the developing retina comes from studies in the frog and fish (Negishi et al., 1982; Reh and Tully, 1986; Reh, 1987; Hitchcock et al., 1988). In these animals, the density of particular cell types controls the additional production of that cell type by the germinal cells. If this mechanism were also active during neurogenesis of the rat retina, the results of this study could be explained by the following model. The earliest germinal cells committed to becoming retina may have an intrinsic ability to differentiate into ganglion cells; however, after several of these germinal cells begin to differentiate into ganglion cells, they produce a factor that discourages additional ganglion cell differentiation and/or encourages horizontal cell differentiation. Once horizontal cells begin to differentiate, they produce similar factors that limit their continued production. This cycle continues for the other cell types. At any given time, the phenotypes adopted by the germinal cells depend on the balance of these factors present in the microenvironment.

Such a mechanism can account for the normal sequential production of the different retinal cell types, as well as the findings of a recent study of chick retinal neurons (Adler and Hatlee, 1989). In this report, it is argued that photoreceptors are the "default" or "ground state" of germinal cells. Since progressively earlier dissociation results in cultures with a higher proportion of photoreceptors. This interpretation is not consistent with our results since dissociation of the retina at E14 results in fewer photoreceptors differentiating in the rat cultures than dissociation at P1; however, the model presented above can account for both the chick and rat experiments. Since the predominant photoreceptor in the chick retina is the cone, and these cells are among the first to become postmitotic in the retina, then the model presented in this study would predict that chick retinal germinal cells, induced to differentiate by dissociation, will differentiate into cones with a greater frequency 
in cultures from earlier stages than later stages. However, if Adler and Hatlee had monitored ganglion cells separately 'rom other "multipolar neurons," their percentage should als increase with earlier dissociation. Further characterization ' 'the chick cultures will be necessary to resolve this issue.

We have no evidence concerning whether the sort of " phenotype expression molecules" proposed in this study might be cell surface molecules or diffusible factors. However, the results of several in vivo studies suggest that germinal cells are committed to a particular neuronal phenotype close to their final mitotic division prior to their migration (Hinds and Hinds, 1978; Bennett, 1987; McLoon and Barnes, 1989) and therefore it is likely that these factors act over very short range. Coculturing E14 and P1 cells would be one way of directly testing for these factors, and these experiments are now in progress.

\section{References}

Adler, R., and M. Hatlee (1989) Plasticity and differentiation of embryonic retinal cells after terminal mitosis. Science 243: 391-393.

Akagama, K., and C. J. Barnstable (1986) Identification and characterization of cell types in monolayer cultures of rat retina using monoclonal antibodics. Brain Res. 383: 110-120.

Araki, M., Y. Iida, S. Taketami, M. Watanabe, K. Ohta, and J. Saito (1987) Characterization of photoreceptor cell differentiation in the rat retinal cell culture. Dev. Biol. 124: 239-247.

Barnstable, C. J., and U. C. Drager (1984) Thy-1 antigen: A ganglion cell specific marker in rodent retina. Neuroscience $11: 847-855$.

Bennett, G. S. (1987) Changes in intermediate filament composition during neurogenesis. Curr. Top. Dev. Biol. 21: 151-183.

Benowitz, L. I., P. J. Apostolides, N. Perrone-Bizzozero, S. P. Finkelstein, and H. Zwiers (1988) Anatomical distribution of the growth association protein GAP 43/B-50 in the adult rat brain. J. Neurosci. 8: 339-352.

Blanks, J. C., and D. Bok (1977) An autoradiographic analysis of postnatal cell proliferation in the normal and degenerative mouse retina. J. Comp. Neurol. 174: 317-328.

Bok, P. D. (1968) Nucleic Acid Metabolism and Cell Differentiation in Vertebrate Photoreceptors: An Autoradiographic, Electron Microscopic, and Radiobiochemical Study. Ph.D. Dissertation, UCLA.

Carter-Dawson, L. D., and M. M. LaVail (1979) Rods and cones in the mouse retina. II. Autoradiographic analysis of cell generation using tritiated thymidine. J. Comp. Neurol. 188: 263-272.

Cohen, J., J. F. Burne, J. Winter, and P. Bartlett (1986) Retinal ganglion cells lose response to laminin with maturation. Nature 322 : 465-467.

Cowan, W. M., and T. E. Finger (1982) Regeneration and regulation in the developing central nervous system with special reference to the reconstitution of the optic tectum of the chick following removal of the mesencephalic alar plate. In Neuronal Development, N. C. Spitzer, ed., pp. 377-412, Plenum, New York.

Detwiler, S. R. (1945) The results of unilateral and bilateral extirpation of the forebrain of Amblystoma. J. Exp. Zool. 100: 103-115.

Detwiler, S. R. (1946) Midbrain regeneration in Amblystoma. Anat. Rec. 94: 229-241.

Drager, U. C. (1983) Coexistence of neurofilaments and vimentin in a neuron of the adult mouse retina. Nature 303: 169.

Goslin, K., D. J. Schreyer, J. H. P. Skene, and G. Banker (1988) Development of neuronal polarity: GAP-43 distinguished axonal from dendritic growth cones. Nature 336: 672-674.

Harrison, R.G. (1947) Wound healing and reconstitution of the central nervous system of the amphibian embryo after removal of parts of the neural plate. J. Exp. Zool. 106: 27-45.

Herrup, K., and R. Williams (1987) The control of neuron number. Annu. Rev. Neurosci. 11: 423-454.

Hicks, D., and C. J. Barnstable (1987) Different rhodopsin monoclonal antibodies reveal different binding patterns on developing and adult rat retina. J. Histochem. Cytochem. 35: 1317-1328.

Hicks, D., and Y. Courtois (1988) Acidic fibroblast growth factor stimulates opsin levels in retinal photoreceptor cells in vitro. FEBS Lett. 234: 475-479.

Hinds, J. W., and P. L. Hinds (1978) Early development of amacrine cells in the mouse retina: An electron microscopic, serial section analysis. J. Comp. Neurol. 179: 277-300.

Hinds, J. W., and P. L. Hinds (1979) Differentiation of photoreceptors and horizontal cells in the embryonic mouse retina: An electron microscopic serial section analysis. J. Comp. Neurol. 187: 495-512.

Hitchcock, P. F., P. A. Raymond, and F. Palopoli (1988) Neuronal proliferation and ocular enlargement in black moon goldfish. Int. Symp. Ret. Dev. Regen. Banff, Alberta, Canada.

Hollyfield, J. G. (1968) Differential addition of cells to the retina in Rana pipiens tadpoles. Dev. Biol. 18: 163-179.

Holt, C. E., T. W. Bertsch, H. M. Ellis, and W. A. Harris (1988) Cellular determination in the Xenopus retina is independent of lineage and birth date. Neuron $1:$ 15-26.

Jacobson, M. (1978) Developmental Neurobiology, Plenum, New York.

Kahn, A. J. (1974) An autoradiographic analysis of the time of appearance of neurons in the developing chick neural retina. Dev. Biol. 38: $30-40$.

Laemmli, U. K. (1970) Cleavage of structural proteins during the assembly of the head of bacteriophage T4. Nature 227: 680-685.

Leifer, D., B. S. Lipton, C. J. Barnstable, and R. H. Masland (1984) Monoclonal antibody to thy 1 enhances regeneration of processes by rat retinal ganglion cells in culture. Science 232: 303-306.

McCaffery, C. A., T. R. Raju, and M. R. Bennett (1984) Effects of cultured astroglia on the survival of neonatal rat retinal ganglion cells in vitro. Dev. Biol. 104: 441-448.

McLoon, S. C., and R. B. Barnes (1989) Early differentiation of retinal ganglion cells: An axonal protein expressed by premigratory and migrating retinal ganglion cells. J. Neurosci. 9: 1424-1432.

Morrest, D. K. (1970) The pattern of neurogenesis in the retina of the rat. Z. Anat. Entwickl-Gesch. 131: 45-67.

Negishi, K., T. Teranishi, and S. Kato (1982) New dopaminergic and indolamine-accumulating cells in the growth zone of goldfish retinas after neurotoxic destruction. Science 216: 747-749.

Raju, T. R., and M. R. Bennett (1986) Retinal ganglion cell survival requirements: A major but transient dependence in Muller glia during development. Brain Res. 383: 165-176.

Rappaport, D. H., and J. Stone (1983) The topography of cytogenesis in the developing retina of the cat. J. Neurosci. 3: 1824-1834.

Rappaport, D. H., M. M. LaVail, and P. Rakic (1988) Sequence and topography of cell birth in monkey retina. Int. Symp. Dev. Regen. Banff, Alberta, Canada.

Reh, T. A. (1987) Cell-specific regulation of neuronal production in the larval frog retina. J. Neurosci. 1: 3317-3324.

Reh, T. A., and T. Tully (1986) Regulation of tyrosine hydroxylase containing amacrine cell number in larval frog retina. Dev. Biol. 129: 283-293.

Shaw, G., and K. Weber (1983) The structure and development of the rat retina: An immunofluorescence microscopical study using antibodies specific for intermediate filament proteins. Eur. J. Cell Biol. 30: 219-232.

Sidman, R. L. (1961) Histogenesis of the mouse retina studies with thymidine- $\mathrm{H}^{3}$. In The Structure of the Eye, G. K. Smelser, ed., pp. 487-506, Academic, New York.

Sternberg, P. W. (1988) Control of cell fates within equivalence groups in C. elegans. Trends Ncurosci. 11:259-264.

Sternberg, P. W., and H. R. Horvitz (1984) The genetic control of cell lineage during nematode development. Annu. Rev. Genet. 18: 489524.

Turner, D. L., and C. L. Cepko (1987) A common progenitor for neurons and glia persists in rat retina late in development. Nature 328: 131-136.

Wetts, R., and S. E. Fraser (1987) Multipotent precursors can give rise to all major cell types of the frog retina. Science 239: 1142-1145.

Wigley, C. B., and M. Berry (1988) Regeneration of adult rat retinal ganglion cell processes in monolayer culture: Comparisons between cultures of adult and neonatal neurones. Dev. Brain Res. 42: 85-98.

Young, R. W. (1985) Cell differentiation in the retina of the mouse. Anat. Rec. 212: 199-205.

Zimmerman, R. P., E. H. Polley, and R. L. Fortney (1988) Cell birthdays and rate of differentiation of ganglion and horizontal cells of the developing cat's retina. J. Comp. Neurol. 274: 77-90.

Zwiers, H., A. B. Oestreicher, M. A. Bisby, P. N. E. DeGraan, and W. H. Gispen (1987) Protein kinase C substrate B50 in adult and developing brain is identical to axonally transported GAP43 in regenerating peripheral rat nerve. In Axonal Transport, R. S. Smith and M. A. Bisby, eds., pp. 421-433, Liss, New York. 